\title{
PARAMETER IDENTIFIABILITY METHOD BASED ON THE PARAMETER-OUTPUT SENSITIVITY MATRIX FOR A SOLID- STATE FERMENTATION PROCESS
}

\author{
C. L. da SILVEIRA ${ }^{1}$, M. A. MAZUTTI ${ }^{1}$ e N. P. G. SALAU ${ }^{1}$ \\ ${ }^{1}$ Universidade Federal de Santa Maria, Departamento de Engenharia Química \\ E-mail para contato: christiansilveira86@gmail.com
}

\begin{abstract}
Solid-state fementation processes are still hindered by reactor excessive heating due to growth of the microorganisms. To overcome this problem, the process must be controlled. Modeling and simulation may help the control development, and for this procedure parameter estimation is an important step. Not all parameters are always estimable, which lead us to an identifiability problem. In this work a parameter identifiability analysis is taken for a solid-state fermentation model with six state variables to evaluate the most important parameters set used in the model. The reduction from 17 to 10 parameters to be estimated in the model led to a better fitting of the model to the experimental data.
\end{abstract}

\section{INTRODUCTION}

Solid-state fermentation (SSF) is a fermentation process that involves solids without or very few free water, and the substrate must have only enough moisture to enable the microorganisms to grow (Pandey, 2003). Agricultural wastes can be used as substrate on this process, so their cost with medium tend to be lower. Also, the products of SSF are easier to recover than the ones of submerged fermentation due their high concentration (Rahardjo et al., 2006). Moreover, Farinas et al. (2011) reported that enzymes produced by SSF are more stable against changes in temperature and $\mathrm{pH}$, and their susceptibility to substrate inhibition is decreased.

However, problems like reactor excessive heating are still difficulting process scaling-up. The growth of the microorganisms generates heat, and this heating may become a hard process control (Hölker and Lenz, 2005), which may be overcome with process modeling and simulation and parameters optimization (Lenz et al, 2004).

Good assumptions and parameters estimation are essential for a reliable model for simulation (Schwaab and Pinto, 2007). Therefore, it is needed an objective function to be minimized, i.e. to minimize the errors between experimental and simulated data (Silveira et al., 2014; Schwaab et al., 2008). However, not all parameters are always possible to be estimated, and there are even cases when reducing the numbers of model parameters can lead to better solutions (Li et al., 2004; Secchi et al., 2006).

In this work is performed a parameters identifiability analysis for a solid-state fermentation model, which includes biomass growth, temperature profile, substrate, ethanol, $\mathrm{CO}_{2}$ and $\mathrm{O}_{2}$ as states, in order to evaluate the most important parameters used in the referred model. 


\subsection{The SSF Model and parameters}

The model used in this work is composed by 6 Ordinary Differential Equations, 1 Partial Differential Equation, which was discretized for the bed height, and 5 auxiliary Algebraic Equations, cf. Equation 1-12. This model is an extension of the models proposed by Fanaei and Vaziri (2008) and Silveira et al. (2014). Equation 1 describes de cells growth and it is dependent of Equation 2, which is a physiological state of the cells time-dependent. Equation 3 represents a energy balance of the reactor.

$$
\begin{aligned}
& d X / d t=\mu \Phi X\left(1-X / X_{m}\right) \\
& d \Phi / d t=\gamma_{s} \Phi\left(1-\Phi^{\alpha}\right)-\gamma_{d} \Phi \\
& \partial T / \partial t=\left[\rho_{s}(1-\varepsilon) Y_{Q}(d X / d t)+\rho_{a} C_{p a} V_{z}(\partial T / \partial z)+\rho_{a} f \lambda V_{z}(\partial T / \partial z)\right] /\left(\rho_{b} C_{p b}\right)
\end{aligned}
$$

Equations 4 to 7 describes the substrate consumption and the production of ethanol (product), $\mathrm{CO}_{2}$ and $\mathrm{O}_{2}$.

$$
\begin{aligned}
& d S / d t=Y_{S / X} d X / d t \\
& d P / d t=Y_{P / X} d X / d t \\
& d C O_{2} / d t=Y_{C O 2 / X} d X / d t \\
& d O_{2} / d t=Y_{O 2 / X} d X / d t
\end{aligned}
$$

Equations 8 to 12 describes some parameters used in the previous equations through algebraic equations.

$$
\begin{aligned}
& \mu=\mu_{\max } S /\left(K_{s}+S-k_{l} S^{2}\right) \\
& \rho_{b}=\varepsilon \rho_{a}+(1-\varepsilon) \rho_{s} \\
& C_{p b}=\left[\varepsilon \rho_{a}\left(C_{p a}+f \lambda\right)+(1-\varepsilon) \rho_{s} C_{p s}\right] / \rho_{b} \\
& \gamma_{s}=\gamma_{s 0} \exp \left[-E_{s} /(R(T+273))\right] \\
& \gamma_{d}=\gamma_{d 0} \exp \left[-E_{d} /(R(T+273))\right]
\end{aligned}
$$


So, the parameters chosen initially to be estimated are: $\mu_{\max }, K_{s}, k_{l}$, ?], $\rho_{s}, C_{p s}, \rho_{a}, \alpha, Y_{x / s}$, $Y_{P / x}, Y_{x / O 2}, Y_{x / C O 2}, Y_{q}, E_{s}, E_{d}, \gamma_{s 0}, \gamma_{d 0}$

The routine for the sensibility matrix computing was based in the Equation 13.

$$
d W x(x, \theta) / d t=J x(x, x) W x(x, \theta)+J p(x, \theta)
$$

Where $W x(x, \theta)$ are the parameter-output sensitivity elements, $J x(x, x)$ are the Jacobian derivatives of each state equation for each state variable and $J p(x, \theta)$ are the Jacobian derivatives for each state equation for each estimated parameter.

The objective function chosen to measure the error was the Least Squares, i.e. the quadratic difference between the experimental and the simulated data for all the state variables that were measured (cells, temperature, substrate, product, $\mathrm{O}_{2}$ and $\mathrm{CO}_{2}$ ), conform Equation 14.

$$
F_{o b j}=\sum\left(y_{\text {exp }}-y_{\text {mod }}\right)^{2}
$$

\section{MATERIAL AND METHODS}

The experimental data were obtained by Mazutti et al. (2010). The experiments were carried out by 24 hours and the measure was taken hour-by-hour. Further details can be found on Mazutti et al. (2010) and Silveira et al. (2014) works.

All the analysis were performed using implementations with the software Matlab®. The model parameter estimation was performed using a nonlinear least squares function (lsqnonlin). The numerical integrator used was a Dormand-Prince pair, based on a Runge-Kutta of $4^{\text {th }}$ and $5^{\text {th }}$ order, for non-stiff differential equations (Dormand and Prince, 1980). The computer used for the procedures has an Intel ${ }^{\circledR}$ Core ${ }^{\mathrm{TM}} \mathrm{i} 7-3770$ with $3.40 \mathrm{GHz}$ processor and $12 \mathrm{~Gb}$ of RAM memory and it is running with the Windows 764 bits Operating System.

\section{RESULTS AND DISCUSSION}

The parameters sensitivity matrix was computed through Equation 13 using all parameters, i.e. 17 parameters. Table 1 presents the matrix obtained, which shows that $\mu_{\max }, K_{s}, k_{l}, Y_{x / s}, Y_{P / x}$, $Y_{x / O 2}, Y_{x / C O 2}, Y_{q}$ are unindentifiable for none of the 7 state equations used in the model. In this manner, they were cut off the parameter estimation, receiving just a constant value which may be suitable for the experimental data.

Table 1 - Parameters sensitivity matrix

\begin{tabular}{|l|l|l|l|l|l|l|l|}
\hline & Cells & Temperature & Substrate & Ethanol & $\Phi$ & $\mathrm{O}_{2}$ & $\mathrm{CO}_{2}$ \\
\hline$\mu_{\max }$ & 0 & 0 & 0 & 0 & 0 & 0 & 0 \\
\hline
\end{tabular}




\begin{tabular}{|l|l|l|l|l|l|l|l|}
\hline $\mathrm{K}_{\mathrm{s}}$ & 0 & 0 & 0 & 0 & 0 & 0 & 0 \\
\hline $\mathrm{k}_{1}$ & 0 & 0 & 0 & 0 & 0 & 0 & 0 \\
\hline$\varepsilon$ & 0 & $-1.6600 \mathrm{E}-07$ & 0 & 0 & $-4.394 \mathrm{E}-12$ & 0 & 0 \\
\hline$\rho_{\mathrm{s}}$ & 0 & $4.5339 \mathrm{E}-08$ & 0 & 0 & $1.200 \mathrm{E}-12$ & 0 & 0 \\
\hline $\mathrm{C}_{\mathrm{ps}}$ & 0 & $4.1981 \mathrm{E}-07$ & 0 & 0 & $1.111 \mathrm{E}-11$ & 0 & 0 \\
\hline$\rho_{\mathrm{a}}$ & 0 & $-1.5113 \mathrm{E}-10$ & 0 & 0 & $-4.000 \mathrm{E}-15$ & 0 & 0 \\
\hline$\alpha$ & 0 & 0 & 0 & 0 & $7.343 \mathrm{E}-11$ & 0 & 0 \\
\hline $\mathrm{Y}_{\mathrm{x} / \mathrm{s}}$ & 0 & 0 & 0 & 0 & 0 & 0 & 0 \\
\hline $\mathrm{Y}_{\mathrm{P} / \mathrm{x}}$ & 0 & 0 & 0 & 0 & 0 & 0 & 0 \\
\hline $\mathrm{Y}_{\mathrm{x} / \mathrm{O} 2}$ & 0 & 0 & 0 & 0 & 0 & 0 & 0 \\
\hline $\mathrm{Y}_{\mathrm{x} / \mathrm{CO} 2}$ & 0 & 0 & 0 & 0 & 0 & 0 & 0 \\
\hline $\mathrm{Y}_{\mathrm{q}}$ & 0 & 0 & 0 & 0 & 0 & 0 & 0 \\
\hline $\mathrm{E}_{\mathrm{s}}$ & 0 & 0 & 0 & 0 & $-1.3638 \mathrm{E}-5$ & 0 & 0 \\
\hline $\mathrm{E}_{\mathrm{d}}$ & 0 & 0 & 0 & 0 & 0.02082 & 0 & 0 \\
\hline$\gamma_{\mathrm{s} 0}$ & 0 & 0 & 0 & 0 & 0.00652 & 0 & 0 \\
\hline$\gamma_{\mathrm{d} 0}$ & 0 & 0 & 0 & 0 & $-4.76 \mathrm{E}+36$ & 0 & 0 \\
\hline
\end{tabular}

In the case of the variable $\mu$, which depends upon $\mu_{\max }, K_{s}$ and $k_{l}$, became a parameter to be directly estimated, so the specific growth rate does not get out of the microorganisms growth equation (Eq. 1). Thus, Equation 8 has been cut off the model.

The parameters whose elements are non-zero for any state variable were maintained for a new estimation. Therefore, the amount of parameters to be estimated has decreased from 17 to 10 . The remaining parameters were estimated in a new simulation and a new objective function was computed according to Equation 14. The comparison between the model with all 17 parameters and with 10 parameters can be seen in Tables 2 and 3, respectively.

Table 2 - Sum of objective function values for each experiment in each state variable for the model with all parameters (17)

\begin{tabular}{|c|l|l|l|l|l|l|}
\hline Experiment & \multicolumn{1}{|c|}{ Cells } & Temperature & \multicolumn{1}{|c|}{ Substrate } & \multicolumn{1}{|c|}{ Ethanol } & \multicolumn{1}{c|}{$\mathrm{O}_{2}$} & \multicolumn{1}{c|}{$\mathrm{CO}_{2}$} \\
\hline 1 & 0.183067 & 0.886802 & 0.228444 & 0.160529 & 0.159687 & 0.135407 \\
\hline 2 & 0.212329 & 0.343354 & 0.25857 & 0.169698 & 0.167935 & 0.080861 \\
\hline 3 & 0.161772 & 0.668343 & 0.308412 & 0.12323 & 0.12167 & 0.0464 \\
\hline 4 & 0.099425 & 0.625356 & 0.07096 & 0.0861 & 0.085678 & 0.093034 \\
\hline 5 & 0.065099 & 0.460677 & 0.271329 & 0.046892 & 0.046255 & 0.038709 \\
\hline 6 & 0.461275 & 0.62593 & 0.400723 & 0.422146 & 0.420535 & 0.346136 \\
\hline 7 & 0.142453 & 0.851488 & 0.807647 & 0.125594 & 0.125016 & 0.119266 \\
\hline Sum & 1.325421 & 4.46195 & 2.346085 & 1.134188 & 1.126775 & 0.859813 \\
\hline
\end{tabular}


Table 3 - Sum of objective function values for each experiment in each state variable for the model with reduced number (10) of parameters

\begin{tabular}{|c|l|l|l|c|c|l|}
\hline Experiment & \multicolumn{1}{|c|}{ Cells } & Temperature & \multicolumn{1}{|c|}{ Substrate } & \multicolumn{1}{c|}{ Ethanol } & \multicolumn{1}{c|}{$\mathrm{O}_{2}$} & \multicolumn{1}{c|}{$\mathrm{CO}_{2}$} \\
\hline 1 & 0.257496 & 0.891319 & 0.212907 & 0.170438 & 0.176417 & 0.160864 \\
\hline 2 & 0.056612 & 0.404933 & 0.26836 & 0.042987 & 0.040103 & 0.06014 \\
\hline 3 & 0.097446 & 0.75927 & 0.306745 & 0.040749 & 0.042754 & 0.043151 \\
\hline 4 & 0.143648 & 0.5843 & 0.071584 & 0.079771 & 0.081926 & 0.081687 \\
\hline 5 & 0.040779 & 0.520592 & 0.184263 & 0.018837 & 0.017888 & 0.030166 \\
\hline 6 & 0.277789 & 0.659184 & 0.335948 & 0.321551 & 0.314702 & 0.350699 \\
\hline 7 & 0.219758 & 0.847304 & 0.737764 & 0.145092 & 0.151003 & 0.135688 \\
\hline Sum & 1.093528 & 4.666902 & 2.117571 & 0.819425 & 0.824793 & 0.862396 \\
\hline
\end{tabular}

As can be seen from Tables 2 and 3, the model whose estimation with only 10 parameters was used performed even better, showing that its sum of the normalized objective function was 10.3846 against 11.2542 of the model with all parameters estimated. The parameters used in both simulations are reported in Table 4.

Table 4 - Parameters values used in both simulations (*were not included in estimation).

\begin{tabular}{|l|l|l|}
\hline Parameters & All parameters estimated & Reduced parameters estimated \\
\hline$\mu_{\max }$ & 0.8243 & $0.8243^{*}$ \\
\hline $\mathrm{K}_{\mathrm{s}}$ & 0.00024 & $0.00024^{*}$ \\
\hline $\mathrm{k}_{1}$ & 0.3109 & $0.3109^{*}$ \\
\hline$\varepsilon$ & 0.9991 & 0.9991 \\
\hline$\rho_{\mathrm{s}}$ & 269.9952 & 269.9952 \\
\hline $\mathrm{C}_{\mathrm{ps}}$ & 2499.9575 & 2499.9575 \\
\hline$\rho_{\mathrm{a}}$ & 0.9000 & 0.9000 \\
\hline$\alpha$ & 11.0000 & 11.0000 \\
\hline $\mathrm{Y}_{\mathrm{x} / \mathrm{s}}$ & 1.0241 & $1.0241^{*}$ \\
\hline $\mathrm{Y}_{\mathrm{P} / \mathrm{x}}$ & 1.0160 & $1.0160^{*}$ \\
\hline $\mathrm{Y}_{\mathrm{x} / \mathrm{O} 2}$ & 0.9835 & $0.9835^{*}$ \\
\hline $\mathrm{Y}_{\mathrm{x} / \mathrm{CO} 2}$ & 0.9392 & $0.9392^{*}$ \\
\hline $\mathrm{Y}_{\mathrm{q}}$ & $8.3660 \mathrm{E}+06$ & $6.6928 \mathrm{E}+06^{*}$ \\
\hline $\mathrm{E}_{\mathrm{s}}$ & $6.8137 \mathrm{E}+04$ & $6.8137 \mathrm{E}+04$ \\
\hline $\mathrm{E}_{\mathrm{d}}$ & $2.9451 \mathrm{E}+05$ & $2.9451 \mathrm{E}+05$ \\
\hline$\gamma_{\mathrm{s} 0}$ & $9.7603 \mathrm{E}+08$ & $9.7603 \mathrm{E}+08$ \\
\hline$\gamma_{\mathrm{d} 0}$ & $8.7400 \mathrm{E}+45$ & $8.74 \mathrm{e}+45$ \\
\hline
\end{tabular}


Further, Figures 1-3 presents the comparison between experimental data and simulations for each state variable for one experiment, where can be seen that both models are very similar, although the parameter reduction.
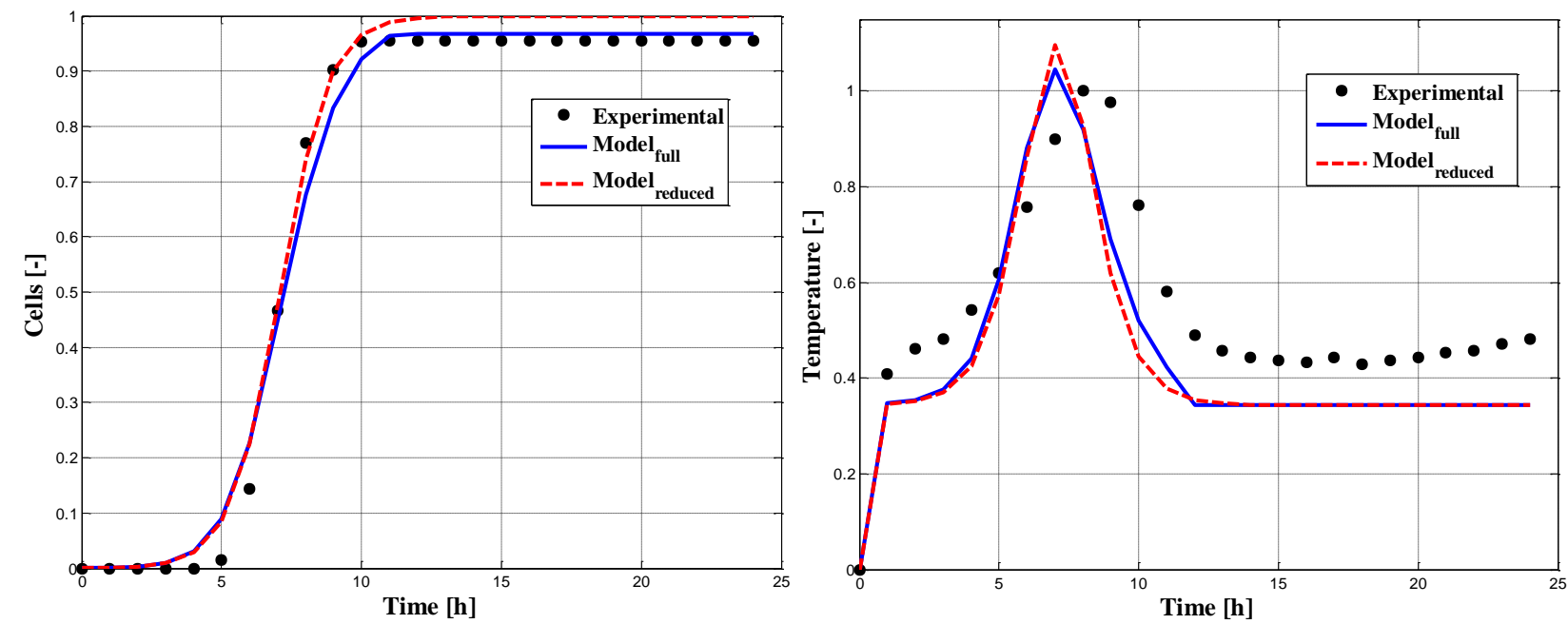

Figure $1-$ a) Cells growth and b) temperature profiles versus time for experimental data, model with all parameters estimated and model with reduced parameters estimated.
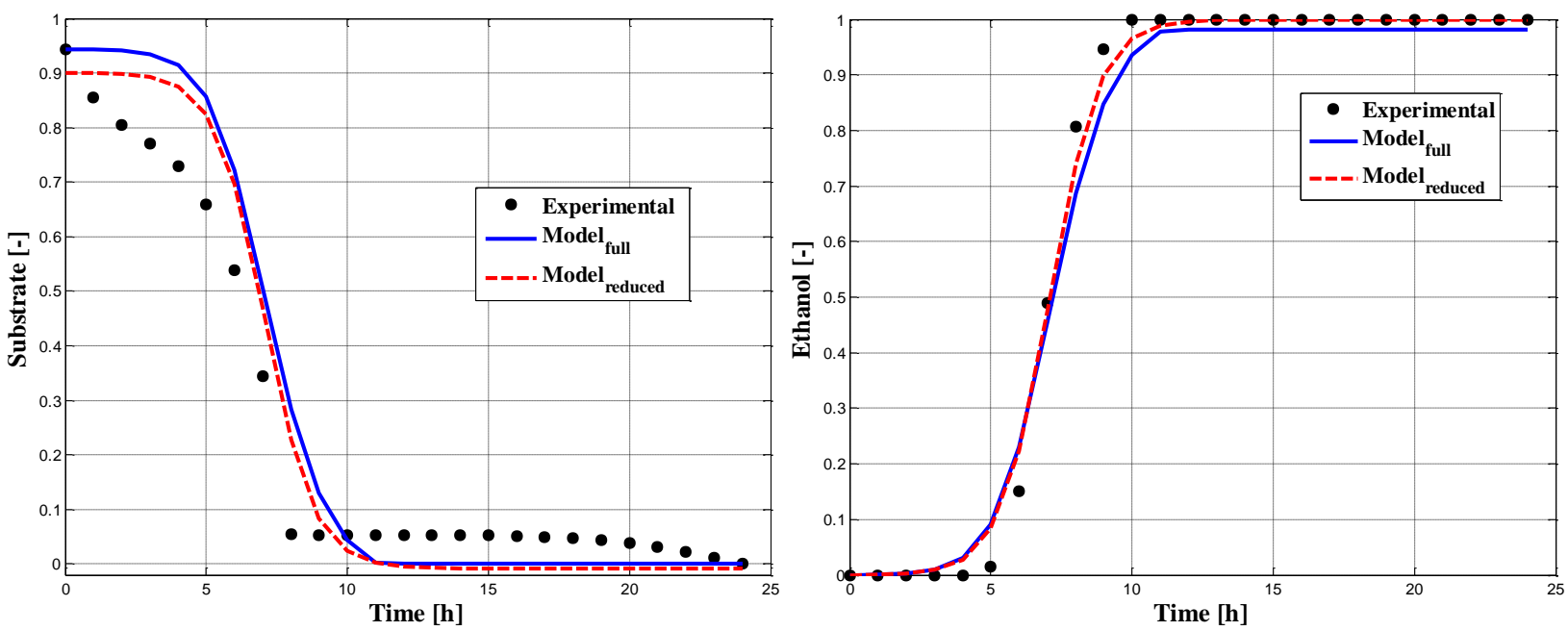

Figure 2-a) Substrate consumption and b) Ethanol production versus time for experimental data, model with all parameters estimated and model with reduced parameters estimated. 

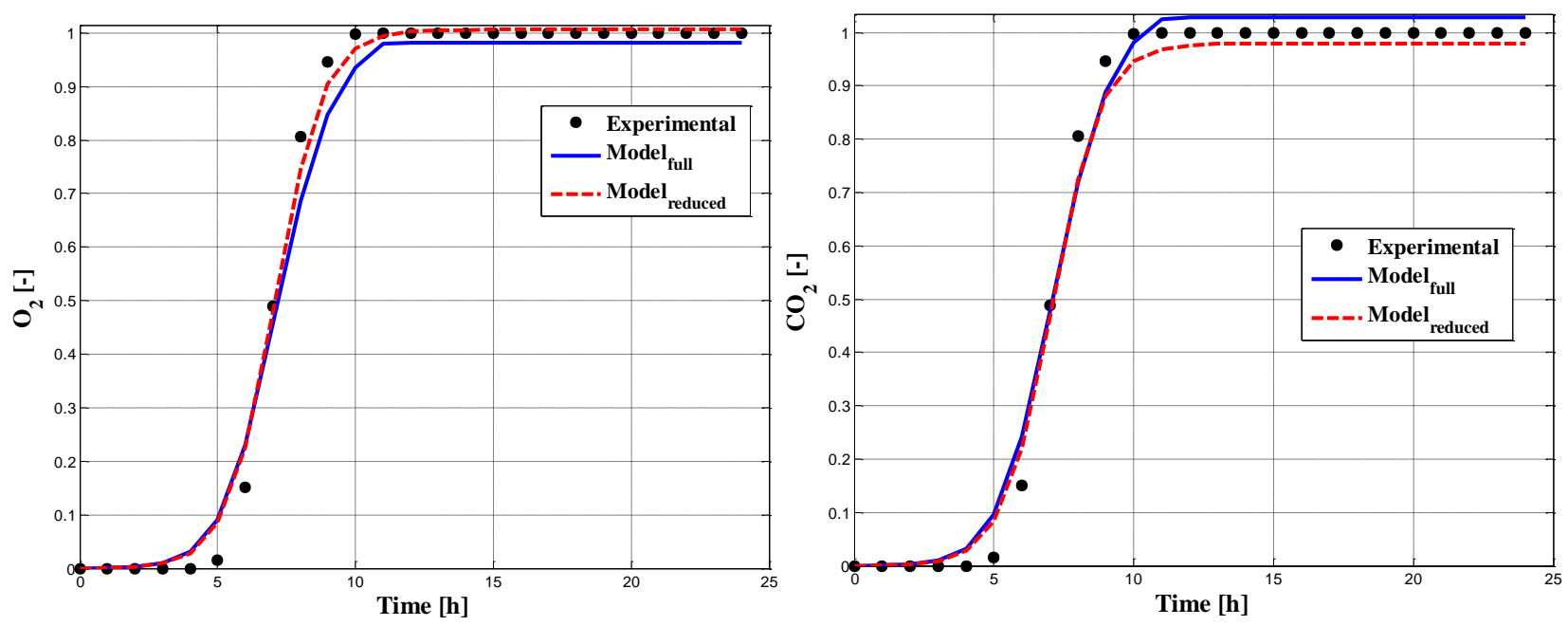

Figure 3 - a) $\mathrm{O}_{2}$ and b) $\mathrm{CO}_{2}$ production versus time for experimental data, model with all parameters estimated and model with reduced parameters estimated.

Figures 1-3 show how close one model is from the other, permitting to conclude once more that even with the reduction of the parameters to be estimated the reliability of the model is still true.

\section{CONCLUSIONS}

Parameters identifiability techniques can be very useful for reduction of parameters of a model. The reduction from 17 to 10 parameters in this model of solid-state fermentation led to a very small reduction of the least squares objective function, which means that the reduction of 7 parameters have not changed the model reliability, or, even more, it increased the precision of the model in a general way.

The obtained results could be used for more statistical analysis or even another parameter reduction. Furthermore, the reduction of parameters could be useful for a process control implementation.

\section{REFERENCES}

DORMAND, J. R.; PRINCE, P. J. A family of embedded Runge-Kutta formulae. Journal of Computational and Applied Mathematics, v. 6(1), p. 19-26, 1980.

FANAEI, M. A.; VAZIRI, B. M. Modeling of temperature gradients in packed-bed solid-state bioreactors. Chem. Engineering and Processing: Process Intensification, v. 48(1), p. 446-451, 2009.

FARINAS, C. S.; VITCOSQUE, G. L.; FONSECA, R. F.; NETO, V. B.; COURI, S. Modeling the effects of solid state fermentation operating conditions on endoglucanase production using and instrumented bioreactor. Industrial Crops and Products, v. 34, p. 1186-1192, 2011.

HÖLKER, U.; LENZ, J. Solid-state fermentation - are there any biotechnological advantages?. 
Current Opinion in Microbiology, v. 8(3), p. 301-306, 2005.

LENZ, J.; HÖFER, M.; KRASENBRINK, J. B.; HÖLKER, U. A survey of computational and physical methods applied to solid-state fermentation. Applied Microbiology and Biotechnology, v. 65(1), p. 9-17, 2004.

LI, R. J.; HENSON, M. A.; KURTZ, M. J. Selection of model parameters for offline parameter estimation. IEEE Transactions on Control Systems Technology, v. 12, p. 402-412, 2004.

MAZUTTI, M. A.; ZABOT, G.; BONI, G.; SKOVRONSKI, A.; OLIVEIRA, D. de; LUCCIO, M. Di; RODRIGUES, M. I.; TREICHEL, H.; MAUGERI, F. Kinetics of inulinase production by solid-state fermentation in a packed-bed bioreactor. Food Chemistry, v. 120, p. 163-173, 2010.

PANDEY, A. Solid-state fermentation. Biochemical Engineering journal, v. 13, p. 81-84, 2003.

RAHARDJO, Y. S. P.; TRAMPER, J.; RINZEMA, A. Modeling conversion and transport phenomena in solid-state fermentation: a review and perspectives. Biotechnology Advances, v. 24, p. 161-179, 2006.

SCHWAAB, M.; PINTO, J. C. Experimental data analysis I. Fundamentals of statistics and parameter estimation. Rio de Janeiro - RJ: E-papers, 2007.

SCHWAAB, M.; BISCAIA, E. C.; MONTEIRO, J. L. Jr.; PINTO, J. C. Nonlinear parameter estimation through particle swarm optimization. Chem. Eng. Science, v. 63, p. 1542-1552, 2008.

SECCHI, A. R.; CARDOZO, N. S. M.; NETO, E. A.; FINKLER, T. F. An algorithm for automatic selection and estimation of model parameters. International Symposium on Advanced Control of Chemical Processes (ADCHEM 2006), Gramado, Brazil, 2006.

SILVEIRA, C. L. da; MAZUTTI, M. A.; SALAU, N. P. G. Modeling the microbial growth and temperature profile in a fixed-bed bioreactor. Bioprocess and Biosys. Eng., Published online (2014). 